\title{
Three Monoterpenoids Eucommiol from The Leaves of Eucommia Ulmoides Protect against Neurotoxicity in PC12 Cells
}

\author{
Yueming ZUO \\ College of Pharmacy \\ Jiangxi University of Traditional Chinese Medicines \\ Nanchang City, Jiangxi Province.China.330004. \\ e-mail: zuo_yueming@163.com
}

\author{
Zhongli ZHANG* \\ College of Pharmacy \\ Jiangxi University of Traditional Chinese Medicines \\ Nanchang City, Jiangxi Province.China.330004. \\ e-mail: zzl51518@163.com
}

\begin{abstract}
One new monoterpenoid compound 4'-acetyleucommiol (1) and two known compounds eucommiol(2), 1deoxyeucommiol(3) were isolated from the leaves of Eucommia ulmoides. The structures of the new monoterpenoid eucommiol were elucidated by means of chemical evidence and 1D-and 2DNMR ( ${ }^{1} \mathrm{H},{ }^{13} \mathrm{C}$, HSQC, HMBC, ${ }^{1} \mathrm{H}-{ }^{1} \mathrm{H}$ COSY and NOESY) spectroscopic analysis and HR-ESI-MS. We also investigated the protective effect of compounds 1-3 on the neurotoxicity of PC12 cells induced by amyloid-beta $\left(A \beta_{25-35}\right)$, respectively. As a result, compounds 1 and 2 were seen to afford protection against A $\beta$-induced toxicity in PC12 cells.
\end{abstract}

Keywords-leaves of Eucommia ulmoides; Cyclohexenone; Eucommiol; PC12

\section{INTRODUCTION}

The leaves of Eucommia ulmoides Oliv.(Eucommiaceae) are widely used as a traditional Chinese medicine in China for its anti-aging, antioxidant, lowering blood pressure, reducing blood lipids and regulate blood suger level[1].In the previous papers, the chemical constituents from the leaves of Eucommia ulmoides Oliv. are reported to be phenylpropanoids[2], flavonoids[3], iridoids[4], and lignans[5],et al. This paper deals with the isolation and structural elucidation of one new monoterpenoid compound 4'-acetyl-eucommiol (1) and two known compounds eucommiol(2), 1-deoxyeucommiol(3)[6], from the $60 \%$ ethanol elution parts of the leaves of Eucommia ulmoides Oliv.The PC12 cell line, derived from rat pheochromocytoma, displays phenotypic characteristics of sympathetic neurons. The cells were grown in the presence of various toxins mimicking the conditions taking place in neurodegenerative diseases, including amyloid-beta (A $\beta$, the peptide composing the amyloid plaques in brains of $\mathrm{AD}$ patients). In this paper, we also investigated the protective effect of compounds $1-3$ on the neurotoxicity of PC12 cells induced by amyloid-beta $\left(\mathrm{A} \beta_{25-35}\right)$, respectively. As a result, compounds 1 and 2 were seen to afford protection against A $\beta$-induced toxicity in PC12 cells. This study will contribute to revealing the chemical basis for the therapeutic effect of Eucommia ulmoides Oliv.

\section{EXPERIMENTAL}

\section{A. General}

HR-ESI-MS were recorded in a Finnigan-LC-QDECA. NMR spectra were recorded on Bruker AM-400. TLC employed precoated silica gel plates $(5-7 \mu \mathrm{m}$, Qingdao Haiyang). For column chromatography, silica gel (H, 100200 and 200-300 mesh, Qingdao Haiyang). HPLC was performed on a waters 515 instrument equipped with a water-UV-2489 detector. A YMC-pack ODS-A $(10 \times 250$ $\mathrm{mm}$, i.d.) column was used for preparative purpose. Compounds were visualized either under UV light or by spraying with $10 \% \mathrm{H}_{2} \mathrm{SO}_{4}$ followed by heating at $100^{\circ} \mathrm{C}$ for 5-10 min.PC12 cells obtained from Institute of biochemistry and cell biology (Shanghai, China) were grow in Dulbecco's modified Eagle's medium (DMEM) (Hyclone, NRH0020), supplemented with 5\% fetal bovine serum and 1\% antibiotix mixture comprising penicillin-streptomycin, in a humidified atmosphere at $37^{\circ} \mathrm{C}$ with $5 \% \mathrm{CO}_{2}$ in $\mathrm{CO}_{2}$ incubator (SANYO, Electric Co., Ltd. Japan). Microplate reader (Biotek, ELx800, America) was used to determine the cell viability.

\section{B. Plant Material}

The leaves of Eucommia ulmoides Oliv were collected from Zhangshu City of Jiangxi province, People’s Republic of China in April 2014 and identified by prof. Yueming Zuo of Jiangxi University of Traditional Chinese Medicines. The voucher specimen (JZ20140406) was deposited at College of Pharmacy, Jiangxi University of Traditional Chinese Medicines, China.

\section{Extraction and Isolation}

The leaves (26kg) of Eucommia ulmoides Oliv were successively extracted 4 times with $70 \%$ ethanol (each $208 \mathrm{~L} \times 4$ ) under reflux for $2 \mathrm{~h}$. The ethanol extracts was combined and evaporated under reduced pressure to afford crude extracts $(4.704 \mathrm{~kg})$ and the residue $(3.677 \mathrm{~kg})$ was scattered and adsorbed by AB-8 macroporous adsorption resin. In accordance with the water elution, 30\% ethanol elution, $60 \%$ ethanol elution, 95\% ethanol elution to give the corresponding water elution parts(1778g), 30\% ethanol elution parts (390g), 60\% ethanol elution parts (570g) and $95 \%$ ethanol elution parts (320g). The 60\% ethanol elution parts (470g) was applied to a silica gel colum using a $\mathrm{CHCl}_{3}-\mathrm{MeOH}$ (100:1 to 0:1) gradient solvent system to give 48 fractions (Fr.1-48). Fr.6 was separated by CC (silica gel; $\mathrm{CHCl}_{3} / \mathrm{MeOH} 20: 1$ to 8:1) and preparation of high performance liquid chromatography $\left(\mathrm{MeOH} / \mathrm{H}_{2} \mathrm{O}\right.$ 1:1) to afford compounds 1 (5 mg), 2(15 mg), 3(10mg).

(1) 4'-acetyl-eucommiol 
a colorless oil.

${ }^{1} \mathrm{H}$ and ${ }^{13} \mathrm{CNMR}$ (DMSO- $d_{6}$ ): Table I. Positive EIS-MS: $\mathrm{m} / \mathrm{z} 253$ [M+Na] ${ }^{+}$, HR-ESI-MS: $\mathrm{m} / \mathrm{z}$ $[\mathrm{M}+\mathrm{Na}]^{+}$253.0632 $\left(\mathrm{C}_{11} \mathrm{H}_{18} \mathrm{O}_{5}\right)$.

\section{RESULTS AND DisCUSSION}

Compound $1, \mathrm{C}_{11} \mathrm{H}_{18} \mathrm{O}_{5}\left(\mathrm{M}^{+}\right.$at $m / z[\mathrm{M}+\mathrm{Na}]^{+}$253.0632), a colorless oil. The ${ }^{1} \mathrm{H}$-and ${ }^{13} \mathrm{C}$-NMR spectra of compound 1 revealed the presence of a double bond group $\left[\delta_{\mathrm{C}}: 129.23(\mathrm{~s}\right.$, C-3) and 142.13(s, C-4)], four oxygenated methylenes [ $\delta_{\mathrm{H}}$ : $4.57\left(2 \mathrm{H}, \mathrm{d}, J=12.8 \mathrm{~Hz}, \mathrm{H}-4\right.$ '), $\delta_{\mathrm{C}}: 59.95\left(\mathrm{~s}, \mathrm{C}-4^{\prime}\right) ; \delta_{\mathrm{H}}: 4.08(1 \mathrm{H}$, d, $\left.J=13.2 \mathrm{~Hz}, \mathrm{H}-3^{\prime} \mathrm{a}\right) / 3.89\left(1 \mathrm{H}, \mathrm{d}, J=13.2 \mathrm{~Hz}, \mathrm{H}-3^{\prime} \mathrm{b}\right), \delta_{\mathrm{C}}$ : 55.60(s, C-3'); 3.92(1H, m, H-1), $\delta_{\mathrm{C}}: 74.33(\mathrm{~s}, \mathrm{C}-1) ; 3.46(2 \mathrm{H}$, $\left.\mathrm{m}, \mathrm{H}-2 "), \delta_{\mathrm{C}}: 62.43(\mathrm{~s}, \mathrm{C}-2 ")\right]$, three methylenes $\left[\delta_{\mathrm{H}}: 2.58(1 \mathrm{H}\right.$, $\mathrm{m}, \mathrm{H}-5 \mathrm{a}) / 2.14(1 \mathrm{H}, \mathrm{m}, \mathrm{H}-5 \mathrm{~b}), \delta_{\mathrm{C}}: 42.42(\mathrm{~s}, \mathrm{C}-5) ; \delta_{\mathrm{H}}: 2.53(2 \mathrm{H}$, $\mathrm{m}, \mathrm{H}-2), \delta_{\mathrm{C}}: 52.63(\mathrm{~s}, \mathrm{C}-2) ; \delta_{\mathrm{H}}: 1.76(1 \mathrm{H}, \mathrm{m}, \mathrm{H}-2 \mathrm{a}) / 1.27(1 \mathrm{H}$, m, H-2'b), $\left.\delta_{\mathrm{C}}: 34.00\left(\mathrm{~s}, \mathrm{C}-2^{\prime}\right)\right]$, a acetyl group $\left[\delta_{\mathrm{H}}: 2.00(3 \mathrm{H}, \mathrm{s}\right.$, $\left.\mathrm{CH}_{3} \mathrm{CO}-\right) ; \delta_{\mathrm{C}}$ : 20.65(s, $\left.\mathrm{CH}_{3} \mathrm{CO}-\right)$ and $\left.170.28\left(\mathrm{~s}, \mathrm{CH}_{3} \mathrm{CO}-\right)\right]$. In the ${ }^{1} \mathrm{H}^{-}{ }^{1} \mathrm{H}$ COSY, cross-peaks were observed between 1$\mathrm{H}$ and $2-\mathrm{H}, 2-\mathrm{H}$ and $2 '-\mathrm{H}, 2 \mathrm{-H}$ and $2 "-\mathrm{H}, 1-\mathrm{H}$ and $5-\mathrm{H}$. These data suggested that 1 was eucommiol basic structure [6]. In the HMBC experiment, the signals of $\delta_{\mathrm{H}}: 4.57(2 \mathrm{H}, \mathrm{d}$, $\left.J=12.8 \mathrm{~Hz}, \mathrm{H}-4^{\prime}\right)$ appeared correlation with $\delta_{\mathrm{C}}: 129.23(\mathrm{~s}$, C$3), 142.13(\mathrm{~s}, \mathrm{C}-4)$ and $170.28\left(\mathrm{~s}, \mathrm{CH}_{3} \mathrm{CO}-\right)$, prompting an acetyl connection with C-4'. On the basis of the above data, the structure of 1 was determined to be as 4'-acetyleucommiol and be as depicted in Table I.

Two known compounds eucommiol(2) and 1-deoxyeucommiol(3)[6], the ${ }^{13} \mathrm{C}-\mathrm{NMR}$ spectra be as depicted in Table I.

The neuroprotective effects of compounds 1-3 against $\mathrm{A} \beta_{25-35}$ induced cell death in PC12 cells were assessed using an established MTT (3-(4, 5-dimethylthiazol-2-yl)-2, 5diphenyl-2H-tetrazolium bromide) assay. $\mathrm{A} \beta_{25-35}$ induced cytotoxicity $(62.76 \pm 1.71 \%)$ in the cells when it was added at a concentration of $20 \mu \mathrm{M}$ for $24 \mathrm{~h}$. When PC12 cells were preincubated with compounds $1-3$, the toxicity of $A \beta_{25-35}$ was significantly alleviated by compounds $1-3$ in a dosedependent manner (Table II). While compounds I and II showed protective effects on the cell viability.

\section{CONCLUSIONS}

We investigated the chemical constituents of Eucommia ulmoides Oliv. Based on its activity towards $\mathrm{AD}$ for the time and three monoterpenoids Eucommiol were obtained. Their structures were identified as 4'-acetyl-eucommiol (1), eucommiol(2), 1-deoxyeucommiol(3), respectively. As a result, compounds 1 and 2 were seen to afford protection against A $\beta$-induced toxicity in PC12 cells. This study will contribute to revealing the chemical basis for the therapeutic effect of Eucommia ulmoides Oliv.

\section{ACKNOWLEDGMENT}

The authors acknowledge the financial support of the National Natural Science Foundation of China,(NSFC) (No.81360632).

\section{REFERENCES}

[1] PENG Ying-zhi, DENG Meng-ru, ZHOU Fang, LIU Shao. Chemical constituents from leaves of eucommia ulmoides collected from Zhangjiajie[J].Central South Pharmacy,2013, 11(3):179-181.

[2] ZHANG Zhong-li, ZUO Yue-ming, LI Yu-yi, CHEN Lan-ying, LIU Rong-hua*. Phenylpropanoids Constituents of Eucommia ulmoides Leaves [J].Journal of Chinese Medicinal Materials, 2014, 37(3):423425.

[3] TANG Fang-rui, ZHANG Zhong-li, ZUO Yue-ming, CHEN Lanying, LUO Jun, LIU Rong-hua*, LI Yu-yi. Chemical Components of flavonoids of Eucommiae Folium [J]. Chinese Journal of Experimental Traditional Medical Formulae, 2014, 20(5):90-92.

[4] ZUO Yue-ming, ZHANG Zhong-Li, WANG Yan-yan, CHEN Lanying, LIU Rong-hua*, LI Yu-yi. Study on Chemical Constituents of Iridoids from Eucommiae Folium [J]. Journal of Chinese Medicinal Matrials, 2014, 37(2):252-254.

[5] ZUO Yue-ming, ZHANG Zhong-li, LI Yu-yi, CHEN Lan-ying, LIU Rong-hua*, WANG Yan-yan. Study on the Chemical Components of lignans of Folium Eucommiae [J]. LISHIZHEN MEDICINE AND MATERIA MEDICA RESEARCH, 2014, 25(6):1317-1319.

[6] ZHANG Zhong-li, ZUO Yue-ming, LI Yu-yi, CHEN Lan-ying, LUO Jun, LIU Rong-hua*. Chemical Constituents of Eucommiae Folium (II) [J]. Chinese Journal of Experimental Traditional Medical Formulae, 2014, 20(20):118-120.

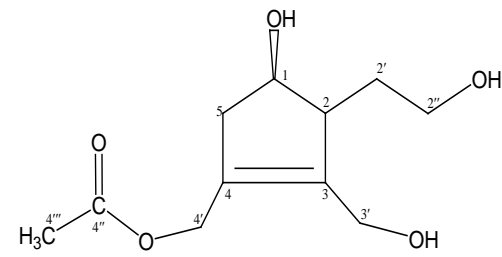

1

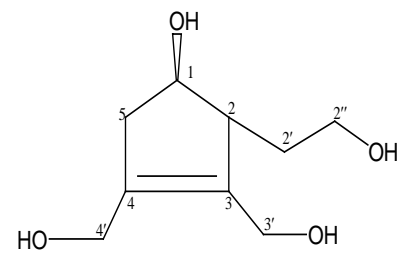

2

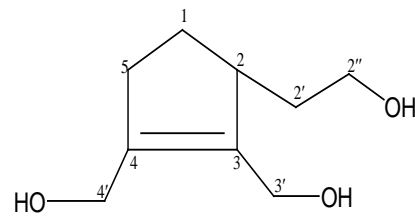

3

Figure 1. Structures of compounds 1-3 
TABLE I. ${ }^{1} \mathrm{H}-\mathrm{NMR}(400 \mathrm{MHZ})$ AND ${ }^{13} \mathrm{C}-\mathrm{NMR}(100 \mathrm{MHZ})$ SPECTROSCOPIC DATA OF COMPOUNDS 1-3(DMSO- $\left.D_{6}\right)$

\begin{tabular}{|c|c|c|c|c|}
\hline \multirow[b]{2}{*}{ position. } & \multicolumn{2}{|c|}{1} & 2 & 3 \\
\hline & $\delta \mathrm{C} / \mathrm{pmm}$ & $\delta \mathrm{H}(\mathrm{J}) / \mathrm{pmm}$ & $\delta \mathrm{C} / \mathrm{pmm}$ & $\delta \mathrm{C} / \mathrm{pmm}$ \\
\hline 1 & 74.33 & 3.92, m & 74.75 & 27.98 \\
\hline 2 & 52.63 & $2.53, \mathrm{~m}$ & 52.56 & 42.97 \\
\hline 3 & 129.23 & & 135.43 & 137.81 \\
\hline 4 & 142.13 & & 137.52 & 139.74 \\
\hline \multirow[t]{2}{*}{5} & 42.42 & $2.58, \mathrm{~m}$ & 42.34 & 36.19 \\
\hline & & $2.14, \mathrm{~m}$ & & \\
\hline \multirow[t]{2}{*}{$2^{\prime}$} & 34.00 & $1.76, \mathrm{~m}$ & 34.24 & 32.72 \\
\hline & & $1.27, \mathrm{~m}$ & & \\
\hline $2 "$ & 62.43 & $3.46, \mathrm{~m}$ & 57.04 & 57.12 \\
\hline \multirow[t]{2}{*}{$3^{\prime}$} & 55.60 & 4.08, d (13.2) & 55.26 & 55.19 \\
\hline & & 3.89, d (13.2) & & \\
\hline $4^{\prime}$ & 59.95 & 4.57, d (12.8) & 59.79 & 59.66 \\
\hline $\mathrm{CH}_{3} \mathrm{CO}-$ & 20.65 & $2.00, \mathrm{~s}$ & & \\
\hline $\mathrm{CH}_{3} \mathrm{CO}-$ & 170.28 & & & \\
\hline
\end{tabular}

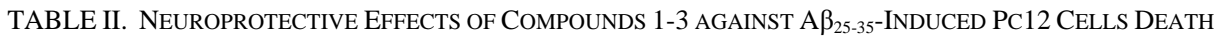

\begin{tabular}{cccc}
\hline \multicolumn{3}{c}{ Cell viability (\%) } \\
\hline Compound & $8 \mu \mathrm{M}$ & $* * 16 \mu \mathrm{M}$ & $* 24 \mu \mathrm{M}$ \\
\hline 1 & $65.50 \pm 3.34$ & $71.38 \pm 4.14$ & $71.91 \pm 1.90$ \\
2 & $64.71 \pm 1.64$ & $65.45 \pm 3.55$ & $72.40 \pm 3.70$ \\
3 & $63.96 \pm 1.99$ & $66.53 \pm 1.84$ & $69.60 \pm 2.63$ \\
\hline
\end{tabular}

Effects of the tested compounds on A $\beta$-induced PC12 cell death.Cell viability was measured by MTT assay. Result are expressed as mean $\pm \mathrm{SD}(\mathrm{n}=6$ ) of two independent experiments. The $100 \%$ value was obtained from untreated control cells. *Significant difference compared $24 \mu \mathrm{M}$ with 8 and $16 \mu \mathrm{M}$ of compounds $1-3\left({ }^{*} \mathrm{p}<0.01\right)$, ${ }^{* *}$ Significant difference compared $16 \mu \mathrm{M}$ with $8 \mu \mathrm{M}$ of compounds $1-3\left({ }^{* *} \mathrm{p}<0.05\right)$ 